NASA/TM-2012-217750

\title{
Advanced Stirling Convertor (ASC-E2) Characterization Testing
}

Zachary D. Williams and Salvatore M. Oriti

Glenn Research Center, Cleveland, Ohio 


\section{NASA STI Program . . . in Profile}

Since its founding, NASA has been dedicated to the advancement of aeronautics and space science. The NASA Scientific and Technical Information (STI) program plays a key part in helping NASA maintain this important role.

The NASA STI Program operates under the auspices of the Agency Chief Information Officer. It collects, organizes, provides for archiving, and disseminates NASA's STI. The NASA STI program provides access to the NASA Aeronautics and Space Database and its public interface, the NASA Technical Reports Server, thus providing one of the largest collections of aeronautical and space science STI in the world. Results are published in both non-NASA channels and by NASA in the NASA STI Report Series, which includes the following report types:

- TECHNICAL PUBLICATION. Reports of completed research or a major significant phase of research that present the results of NASA programs and include extensive data or theoretical analysis. Includes compilations of significant scientific and technical data and information deemed to be of continuing reference value. NASA counterpart of peer-reviewed formal professional papers but has less stringent limitations on manuscript length and extent of graphic presentations.

- TECHNICAL MEMORANDUM. Scientific and technical findings that are preliminary or of specialized interest, e.g., quick release reports, working papers, and bibliographies that contain minimal annotation. Does not contain extensive analysis.

- CONTRACTOR REPORT. Scientific and technical findings by NASA-sponsored contractors and grantees.
- CONFERENCE PUBLICATION. Collected papers from scientific and technical conferences, symposia, seminars, or other meetings sponsored or cosponsored by NASA.

- SPECIAL PUBLICATION. Scientific, technical, or historical information from NASA programs, projects, and missions, often concerned with subjects having substantial public interest.

- TECHNICAL TRANSLATION. Englishlanguage translations of foreign scientific and technical material pertinent to NASA's mission.

Specialized services also include creating custom thesauri, building customized databases, organizing and publishing research results.

For more information about the NASA STI program, see the following:

- Access the NASA STI program home page at http://www.sti.nasa.gov

- E-mail your question to help@sti.nasa.gov

- Fax your question to the NASA STI Information Desk at 443-757-5803

- Phone the NASA STI Information Desk at 443-757-5802

- Write to: STI Information Desk NASA Center for AeroSpace Information 7115 Standard Drive Hanover, MD 21076-1320 
NASA/TM-2012-217750

\section{Advanced Stirling Convertor (ASC-E2) Characterization Testing}

Zachary D. Williams and Salvatore M. Oriti

Glenn Research Center, Cleveland, Ohio

Prepared for the

10th International Energy Conversion Engineering Conference (IECEC) sponsored by the American Institute of Aeronautics and Astronautics Atlanta, Georgia, July 30-August 1, 2012

National Aeronautics and

Space Administration

Glenn Research Center

Cleveland, Ohio 44135 
This report contains preliminary findings, subject to revision as analysis proceeds.

Trade names and trademarks are used in this report for identification only. Their usage does not constitute an official endorsement, either expressed or implied, by the National Aeronautics and Space Administration.

Level of Review: This material has been technically reviewed by technical management.

Available from

NASA Center for Aerospace Information 7115 Standard Drive

Hanover, MD 21076-1320
National Technical Information Service 5301 Shawnee Road Alexandria, VA 22312

Available electronically at http://www.sti.nasa.gov 


\title{
Advanced Stirling Convertor (ASC-E2) Characterization Testing
}

\author{
Zachary D. Williams and Salvatore M. Oriti \\ National Aeronautics and Space Administration \\ Glenn Research Center \\ Cleveland, Ohio 44135
}

\begin{abstract}
Testing has been conducted on Advanced Stirling Convertors (ASCs)-E2 at NASA Glenn Research Center in support of the Advanced Stirling Radioisotope Generator (ASRG) project. This testing has been conducted to understand sensitivities of convertor parameters due to environmental and operational changes during operation of the ASRG in missions to space. This paper summarizes test results and explains the operation of the ASRG during space missions.
\end{abstract}

\section{Introduction}

As a part of the continued support of the Advanced Stirling Radioisotope Generator (ASRG) project's path to flight, Advanced Stirling Convertors (ASCs) from Sunpower, Inc., are on test at NASA Glenn Research Center's (GRC's) Stirling Research Lab (SRL). The latest convertors manufactured and currently under test are the ASC-E2 convertors. Testing is being conducted for extended life reliability and parameter characterization for system integration. To fully understand effects of convertor performance, parameter variation tests need to be conducted.

This paper outlines two tests that were conducted on ASC-E2 convertors. The first test was to support controller development. This test was called the AC bus variation test and was conducted to help understand the sensitivities of key parameters due to AC bus voltage changes. A better understanding of the sensitivities of these parameters will help quantify tolerances of the controller and help finalize control strategies.

The second series of tests was a simulation of argon venting of an ASRG during launch. This testing was to simulate the effect of ascent through the atmosphere during launch of the ASRG and quantify the effects. This series of tests was conducted in three phases. Each of these phases simulated different events that the convertor would undergo throughout the mission.

\section{Nomenclature}

$\begin{array}{ll}\text { ASC } & \text { Advanced Stirling Convertor } \\ \text { ASRG } & \text { Advanced Stirling Radioisotope Generator } \\ \text { BOM HR } & \text { Beginning of Mission High Reject temperature } \\ \text { BOM LR } & \text { Beginning of Mission Low Reject temperature } \\ \text { EU } & \text { Engineering Unit } \\ \text { GRC } & \text { Glenn Research Center } \\ \text { SRL } & \text { Stirling Research Lab } \\ \text { W }_{\text {th }} & \text { Watts thermal }\end{array}$

\section{Test Setup}

The ASC-E2 convertors were tested on a test stand that was designed specifically for ASC-E2 testing. These test stands are shown in Figures 1 and 2. Further details can be found in Reference 1. 


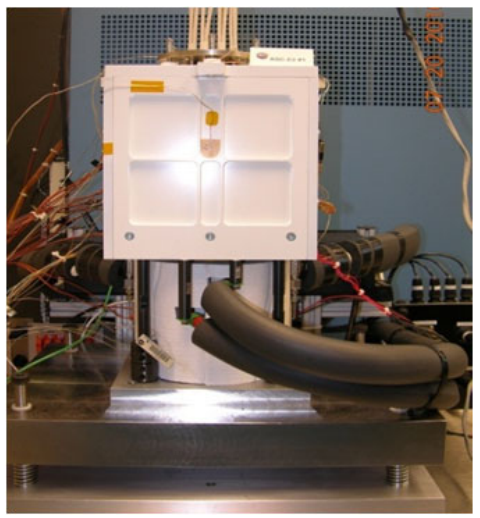

Figure 1.-ASC-E2 \#1 on test stand.

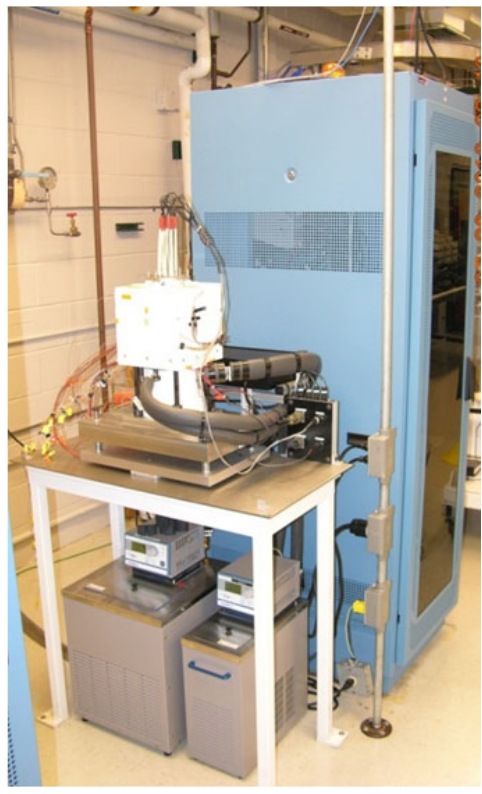

Figure 2.-ASC-E2 \#5 on test stand with test rack in background.

\section{AC Bus Voltage Variation Test}

The AC bus voltage variation test was conducted in the SRL at GRC using ASC-E2 \#1. AC bus voltage is analogous to a key control input to the ASRG. The purpose of this test was to characterize convertor response to AC bus voltage variation.

During testing, the convertor was operating at ASC-E2 specification Beginning of Mission Low Reject (BOM LR) conditions (Ref. 2) in a single-vertical setup with heater head up. The convertor was being controlled with constant heat input. More information on test stations in the SRL can be found in Reference 2.

The test was terminated when the compact electrical heat source failed. After failure, the compact heat source was replaced with an HT FIREROD (Watlow) heat source, and the first four points of the test were repeated. Further details on the HT FIREROD heat source can be found in Reference 3.

The test was conducted by adjusting the AC bus voltage in incremental steps while observing hot-end temperatures with other convertor parameters held constant. The AC bus voltage directly controls the piston amplitude of the convertor. An increase in AC bus voltage results in an increase in piston amplitude. During the test, the AC bus voltage was increased by an increment every day and then the system was allowed at least $8 \mathrm{~h}$ to reach a steady-state point.

Data was gathered using a LabVIEW (National Instruments) data acquisition system. Most parameters were sampled at $2000 \mathrm{~Hz}$ and averaged over $1 \mathrm{sec}$. The averaged data, called 2-sec data, was saved every 2 sec. For steady-state data, the 2-sec data was averaged over a 5 min time span and was saved as a point and is called 5-min average data.

\section{Argon Venting Simulation Test}

The argon venting simulation test was also conducted in the SRL at GRC but was performed using ASC-E2 \#5, which utilizes an HT FIREROD heat source. The purpose of this test was to simulate the convertor environment during launch and collect data useful in developing the launch concept of operation strategies. 
Data was collected for this test using the same type of data acquisition system as the AC bus voltage variation test. This test began with ASC-E2 \#5 operating at ASC-E3 and ASC-F specification BOM-HR. This point was chosen because it better represents the operating condition of a convertor in the payload fairing prior to launch. During this test, the convertor was controlled in constant-heat-input mode.

After the convertor achieved steady state at this point, phase 1 of the test was started. This included decreasing the gross heat input by $20 \mathrm{~W}$ to get a baseline and allow the convertor to reach steady state. Once steady-state conditions were achieved, a 5-min average was recorded and the convertor was returned to a baseline ASC-E3 and ASC-F BOM HR operating point. Again the system was allowed to reach steady state, a 5-min average point was collected, and then the gross heat input was increased by $15 \mathrm{~W}_{\mathrm{th}}$. The convertor was allowed to reach steady state and another 5-min average was taken for this point. The convertor was then returned to a baseline ASC-E3 and ASC-F BOM HR point, allowed to steady, and a final 5-min average point was collected to conclude phase 1.

Phase 2 began with ASC-E2 \#5 operating at ASC-E3 and ASC-F BOM HR conditions. A 5-min average data point was taken to establish a baseline. Subsequently, the net heat input was increased by $30 \mathrm{~W}_{\text {th }}$ to simulate venting of argon and increased effectiveness of thermal insulation. As the hot-end temperature rose, the net heat input was adjusted so that it matched the hot-end temperature/net heat input relationship of the ASRG flight unit. Once the convertor reached a steady state at this point, a 5-min average was taken, and the convertor returned to baseline ASC-E3 and ASC-F BOM HR conditions.

Phase 3 started at steady-state ASC-E3 and ASC-F BOM HR conditions. The next step in this test was to reduce the rejector and alternator housing temperatures by $30{ }^{\circ} \mathrm{C}$. This simulates the sink temperature change as the ASRG ascends from within the spacecraft fairing to the lowest expected radiation sink temperature of $4 \mathrm{~K}$. This represents a worst-case scenario, since a spacecraft leaving Earth's atmosphere sees a radiation sink temperature much higher than $4 \mathrm{~K}$. As the hot-end temperature rose, the net heat input was adjusted to match the hot-end temperature/net heat input relationship of the ASRG flight unit. After this point reached steady state, a 5-min average data point was taken, and the system returned to baseline ASC-E3 and ASC-F BOM HR conditions.

\section{Test Results}

\section{AC Bus Variation Test}

There were nine data points collected with the compact heat source. These points were plotted and can be found in Figure 3. Reported in the graph is 5-min average data from a time in which the convertor reached a steady-state operating point.

From this data the incremental sensitivities of the hot-end temperature and piston amplitude was calculated by dividing the change in the parameter (e.g., change in piston amplitude) by the change in AC bus voltage. The incremental sensitivities that were calculated for piston amplitude and hot-end temperature are plotted versus hot-end temperature in Figure 4.
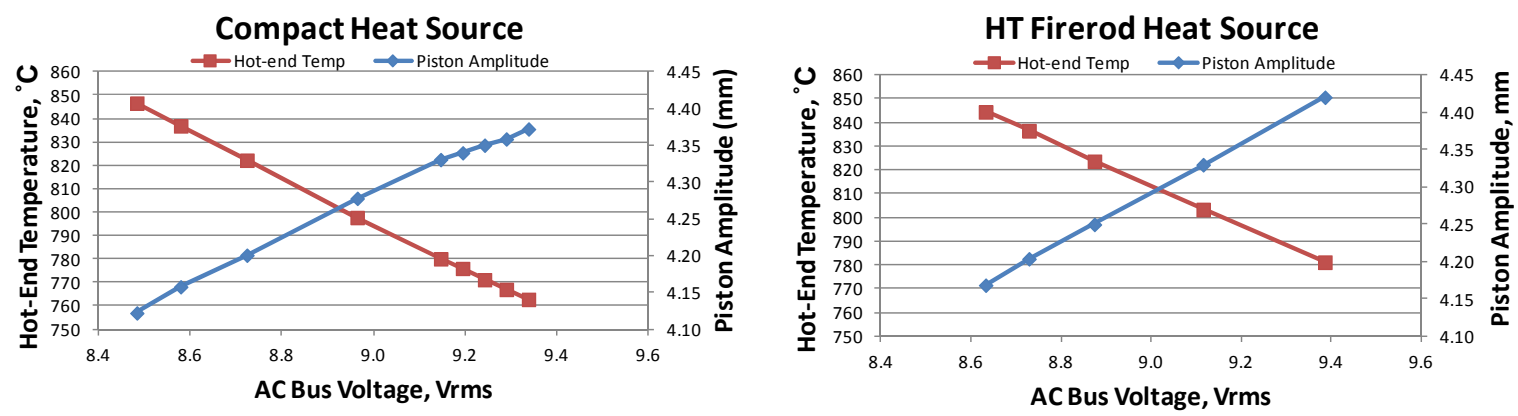

Figure 3.-Data from AC bus voltage variation test. 

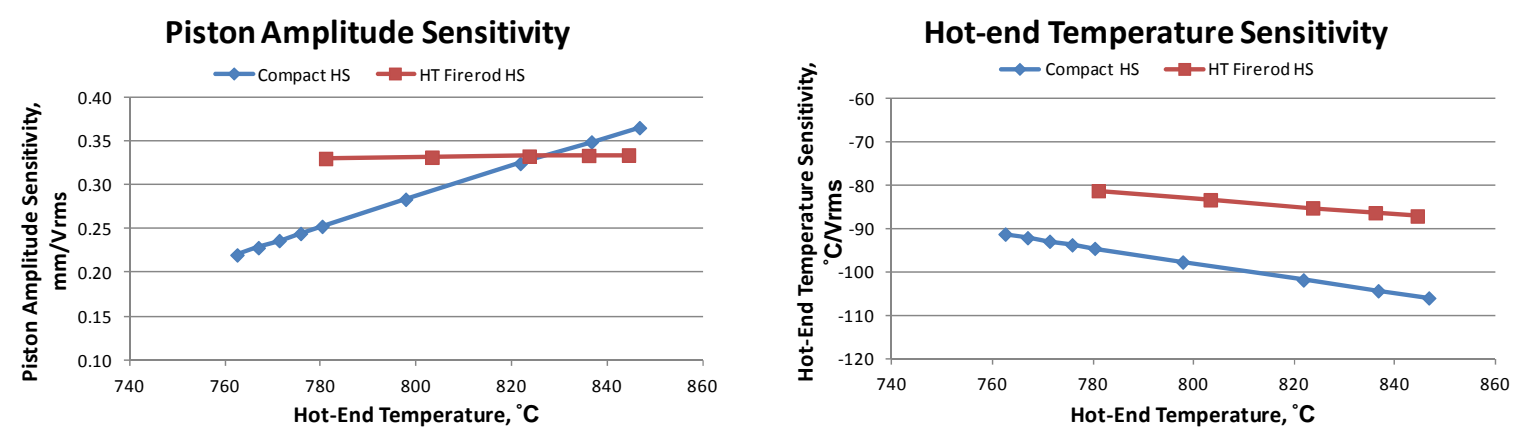

Figure 4.--Sensitivities plotted vs. hot-end temperature.

With the compact heat source, the hot-end temperature sensitivity varied between -91 and $-109{ }^{\circ} \mathrm{C} / \mathrm{V}$ and the piston amplitude sensitivity varied between 0.21 and $0.37 \mathrm{~mm} / \mathrm{V}$. These numbers are similiar to the numbers from the AC bus voltage variation test conducted with the ASRG EU, which had a hot-end temperature sensitivity of -73 to $-81{ }^{\circ} \mathrm{C} / \mathrm{V}$ and a piston amplitude senstivity of 0.23 to $0.30 \mathrm{~mm} / \mathrm{V}$ (Ref. 4). The difference between the operating points may account for some of the differences in the two sets of numbers. The ASRG Engineering Unit (EU) hot-end temperature was about $625^{\circ} \mathrm{C}$ at the beginning of that test and the ASC-E2 \#1 hot-end temperature was at about $850{ }^{\circ} \mathrm{C}$.

After the compact heat source failed, it was replaced with a HT-FIREROD heat source and the first four points of the test were repeated. The results of this repeated test are plotted in Figure 3. The incremental sensitivities were calculated the same way as in the first test. The data was also plotted in Figure 4. The hot-end incremental sensitivities of the second test ranged from -81 to $-89{ }^{\circ} \mathrm{C} / \mathrm{V}$ and the piston amplitude sensitivity varied between 0.32 and $0.35 \mathrm{~mm} / \mathrm{V}$. These slightly higher numbers may be due to changing some of the support hardware for the new heat source which affected the insulation characteristics. The HT FIREROD heat source has greater heat loss compared to the compact heat source, and its heat loss versus temperature characteristics are different. These differences caused changes in hotend temperature and piston amplitude as AC bus voltage was increased or decreased. These test results may differ from test results for the flight ASRG, since the flight ASRG has different thermal characteristics. It should also be mentioned that operation in vacuum will affect system response to AC bus voltage changes.

Some sources of potential error during testing include a failing heater during the first test. This could cause nonuniform heating of the hot-end and could possibly affect the results. Also, ASC-E2 \#1 has a known helium leak that could affect the results and may be a cause of variability while repeating the test.

An interesting observation during testing was the relationship between the alternator terminal voltage and AC bus voltage. As shown in Figure 5, as the AC bus voltage increased, the alternator terminal voltage decreased slightly. While this result in not intuitive, the complex relationship between convertor parameters can produce this result. As AC bus voltage increased, piston amplitude increased, and hot-end temperature decreased. Decreasing hot-end temperature decreased the convertor's mean pressure, which changed the convertor's natural frequency. This led to an increase in the alternator power factor required to maintain the operating frequency. As a result, the alternator terminal voltage decreased slightly for this particular test.

\section{Argon Venting Simulation Test}

Phase 1 of the argon venting simulation test consisted of operating in constant heater power mode then changing gross heat input by $-20 /+15 \mathrm{~W}_{\text {th }}$. This was necessary to gather baseline data for acceptor temperature sensitivity to gross heat input changes. The acceptor temperature is measured at the hot-end heat exchanger inside heater head of the convertor. It is $2.5^{\circ} \mathrm{C}$ lower than the hot-end temperature due to thermocouple locations. Data for each of the points of the test was collected and is plotted in Figure 6. 


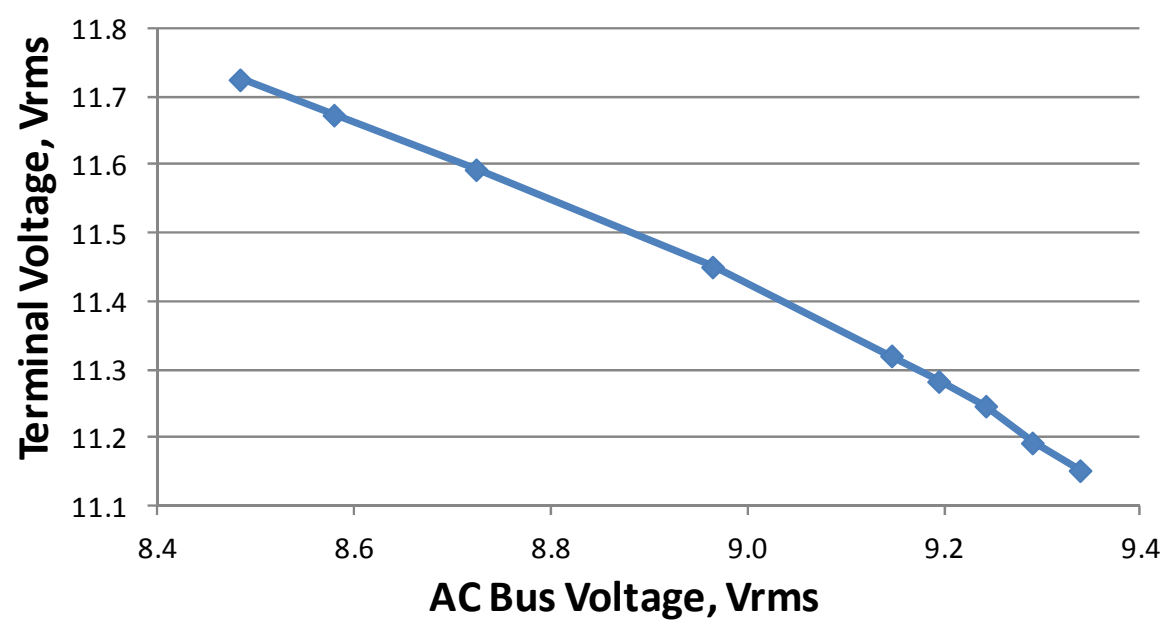

Figure 5.-AC bus voltage and terminal voltage plot.

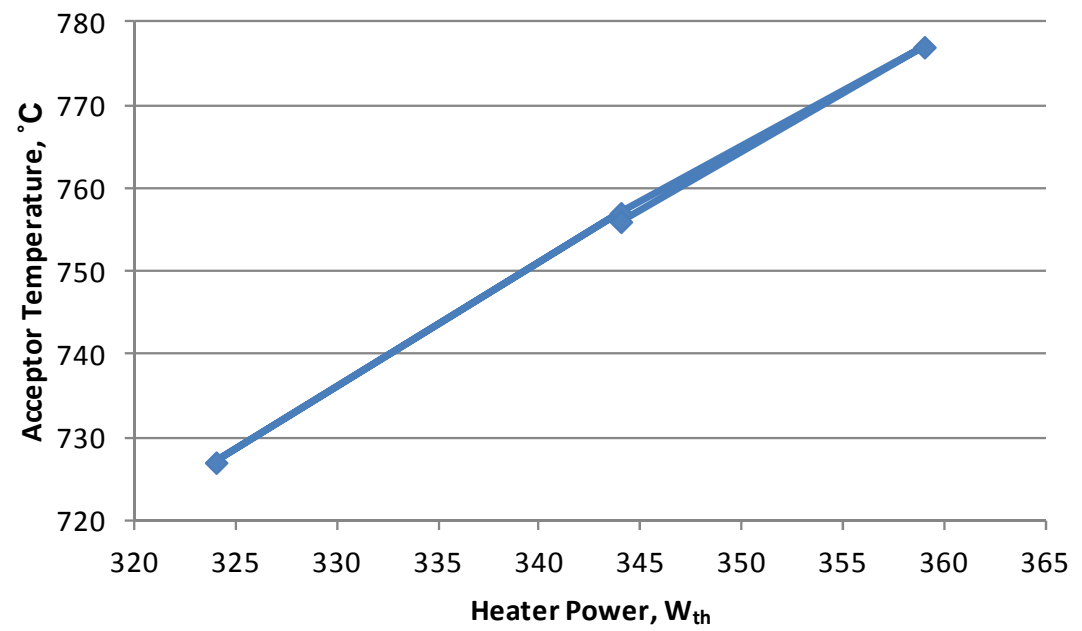

Figure 6.-Argon venting phase 1 results.

The $20 \mathrm{~W}_{\text {th }}$ decrease in gross heat input resulted in a $30{ }^{\circ} \mathrm{C}$ decrease in acceptor temperature. The $15 \mathrm{~W}_{\text {th }}$ increase resulted in a $20^{\circ} \mathrm{C}$ increase in acceptor temperature. Therefore, the sensitivity of acceptor temperature to gross heat input was an average of $1.4^{\circ} \mathrm{C} / \mathrm{W}_{\text {th }}$.

Phase 2 consisted of simulating argon venting by increasing the convertor net heat input. This was accomplished by increasing the net heat input by $30 \mathrm{~W}_{\text {th }}$ (the increase in gross heat input was greater because of the thermal loss characteristics of the insulation package with the HT FIREROD heat source). Data for this phase of the test was collected and is plotted in Figure 7. The net effect of argon venting was an increase in the acceptor temperature by $53^{\circ} \mathrm{C}$ (from 756 to $809^{\circ} \mathrm{C}$ ) due to a net heat input increase of $29 \mathrm{~W}_{\text {th. }}$.

Phase 3 consisted of reducing the rejector and alternator housing temperature to simulate temperature sink change as the generator ascends from storage in the fairing to space. As shown by the plot in Figure 8, the effect of reducing the rejector and alternator housing temperatures by $30{ }^{\circ} \mathrm{C}$ was an increase of the acceptor temperature by $61^{\circ} \mathrm{C}$ (from 760 to $821^{\circ} \mathrm{C}$ ). Therefore, the sensitivity of acceptor temperature to rejector/alternator housing temperature change is $-2.0^{\circ} \mathrm{C} /{ }^{\circ} \mathrm{C}$. 


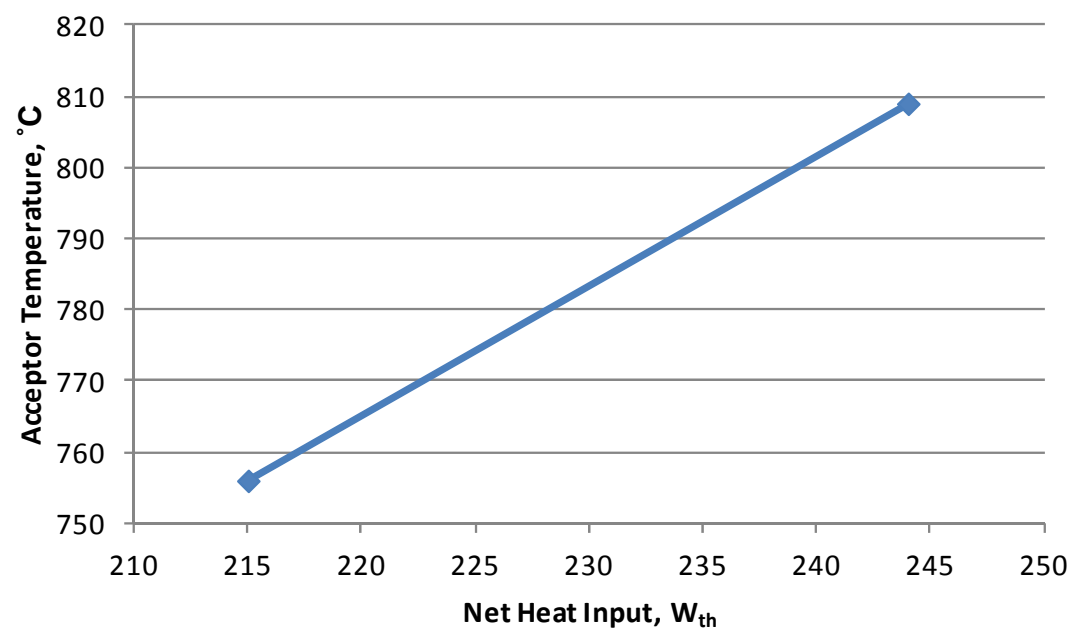

Figure 7.-Argon venting phase 2 results.

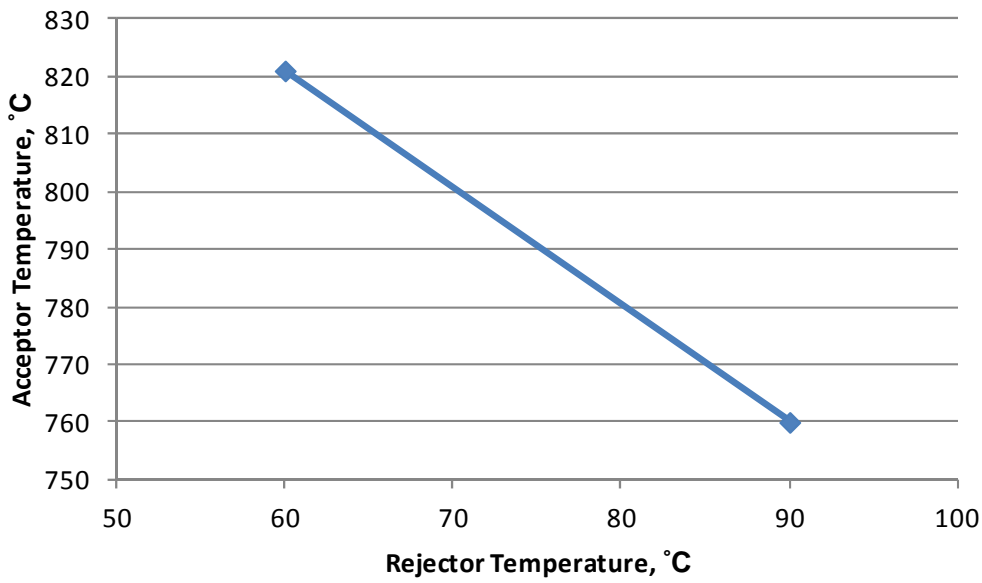

Figure 8.-Argon venting phase 3 results.

\section{Conclusion}

The Advanced Stirling Convertor (ASC)-E2 \#1 sensitivity to AC bus voltage variation is similar to that of the ASC-E convertors in the Advanced Stirling Radioisotope Generator (ASRG) Engineering Unit (EU). This sensitivity is a useful parameter for system integration and control.

The argon venting testing on ASC-E2 \#5 helps us to understand how the convertor will react during the launch stage of a mission. Further testing of mission-specific conditions will help us to understand how the convertor will operate in space.

Performance variation tests need to continue to be conducted on future generations of hardware as the technology matures to the flight configuration. These tests will help advance the ASRG toward flight by providing information to us to fully characterize and understand the convertors and how they will operate in a variety of conditions. 


\section{References}

1. Oriti, S.M., "Extended Operation of Stirling Convertors at NASA Glenn Research Center," International Energy Conversion Engineering Conference, 2011-5726, Vol. 1, AIAA, San Diego, CA, 2011.

2. Oriti, S., and Wilson, S., "Advanced Stirling Convertor (ASC-E2) Performance Testing at NASA Glenn Research Center," Nuclear and Emerging Technologies for Space Conference, CP3496, ANS, AIAA, Albuquerque, NM, 2011.

3. Wilson, S.D., Reid, T.V., Schifer, N.A., and Briggs, M., "Overview of Heat Addition and Efficiency Predictions for an Advanced Stirling Convertor,” International Energy Conversion Engineering Conference, 2011-5576, Vol. 1, AIAA, San Diego, CA, 2011.

4. Lewandowski, E.J., and Schreiber, J.G., "Testing to Characterize the Advanced Stirling Radioisotope Generator Engineering Unit,” International Energy Conversion Engineering Conference, CP6693, Vol. 1, AIAA, Nashville, TN, 2010. 



\begin{tabular}{|c|c|c|}
\hline \multicolumn{2}{|c|}{ REPORT DOCUMENTATION PAGE } & $\begin{array}{l}\text { Form Approved } \\
\text { OMB No. 0704-0188 }\end{array}$ \\
\hline \multicolumn{3}{|c|}{ 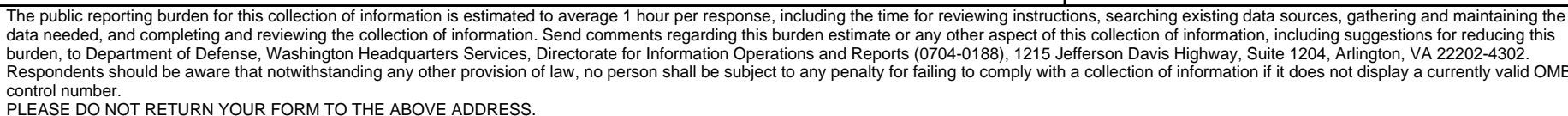 } \\
\hline $\begin{array}{l}\text { 1. REPORT DATE (DD-MM-YYYY) } \\
01-12-2012\end{array}$ & $\begin{array}{l}\text { 2. REPORT TYPE } \\
\text { Technical Memorandum }\end{array}$ & 3. DATES COVERED (From - To) \\
\hline \multirow{3}{*}{\multicolumn{2}{|c|}{$\begin{array}{l}\text { 4. TITLE AND SUBTITLE } \\
\text { Advanced Stirling Convertor (ASC-E2) Characterization Testing }\end{array}$}} & 5a. CONTRACT NUMBER \\
\hline & & 5b. GRANT NUMBER \\
\hline & & 5c. PROGRAM ELEMENT NUMBER \\
\hline \multirow{3}{*}{\multicolumn{2}{|c|}{$\begin{array}{l}\text { 6. AUTHOR(S) } \\
\text { Williams, Zachary, D.; Oriti, Salvatore, M. }\end{array}$}} & 5d. PROJECT NUMBER \\
\hline & & 5e. TASK NUMBER \\
\hline & & $\begin{array}{l}\text { 5f. WORK UNIT NUMBER } \\
\text { WBS } 138494.01 .99 .01\end{array}$ \\
\hline \multicolumn{2}{|c|}{$\begin{array}{l}\text { 7. PERFORMING ORGANIZATION NAME(S) AND ADDRESS(ES) } \\
\text { National Aeronautics and Space Administration } \\
\text { John H. Glenn Research Center at Lewis Field } \\
\text { Cleveland, Ohio 44135-3191 }\end{array}$} & $\begin{array}{l}\text { 8. PERFORMING ORGANIZATION } \\
\text { REPORT NUMBER } \\
\text { E-18223 }\end{array}$ \\
\hline \multirow{2}{*}{\multicolumn{2}{|c|}{$\begin{array}{l}\text { 9. SPONSORING/MONITORING AGENCY NAME(S) AND ADDRESS(ES) } \\
\text { National Aeronautics and Space Administration } \\
\text { Washington, DC 20546-0001 }\end{array}$}} & $\begin{array}{l}\text { 10. SPONSORING/MONITOR'S } \\
\text { ACRONYM(S) } \\
\text { NASA }\end{array}$ \\
\hline & & $\begin{array}{l}\text { 11. SPONSORING/MONITORING } \\
\text { REPORT NUMBER } \\
\text { NASA/TM-2012-217750 }\end{array}$ \\
\hline \multicolumn{3}{|c|}{$\begin{array}{l}\text { 12. DISTRIBUTION/AVAILABILITY STATEMENT } \\
\text { Unclassified-Unlimited } \\
\text { Subject Category: } 20 \\
\text { Available electronically at http://www.sti.nasa.gov } \\
\text { This publication is available from the NASA Center for AeroSpace Information, 443-757-5802 }\end{array}$} \\
\hline
\end{tabular}

\section{ABSTRACT}

Testing has been conducted on Advanced Stirling Convertors (ASCs)-E2 at NASA Glenn Research Center in support of the Advanced Stirling Radioisotope Generator (ASRG) project. This testing has been conducted to understand sensitivities of convertor parameters due to environmental and operational changes during operation of the ASRG in missions to space. This paper summarizes test results and explains the operation of the ASRG during space missions.

\section{SUBJECT TERMS}

Advanced Stirling Convertors (ASCs)

\begin{tabular}{|l|l|l|l|l|l|}
\hline \multicolumn{2}{|l|}{ 16. SECURITY CLASSIFICATION OF: } & $\begin{array}{l}\text { 17. LIMITATION OF } \\
\text { ABSTRACT }\end{array}$ & $\begin{array}{l}\text { 18. NUMBER } \\
\text { OF } \\
\text { PAGES }\end{array}$ & $\begin{array}{l}\text { 19a. NAME OF RESPONSIBLE PERSON } \\
\text { STI Help Desk (email:help@sti.nasa.gov) }\end{array}$ \\
\cline { 1 - 2 } $\begin{array}{l}\text { a. REPORT } \\
\text { U }\end{array}$ & $\begin{array}{l}\text { b. ABSTRACT } \\
\text { U }\end{array}$ & $\begin{array}{l}\text { c. THIS } \\
\text { PAGE } \\
\text { U }\end{array}$ & UU & 14 & $\begin{array}{l}\text { 19b. TELEPHONE NUMBER (include area code) } \\
\text { 443-757-5802 }\end{array}$ \\
\end{tabular}


